\title{
Hana Wa Sakuragi: Discourse Analysis of Cherry Blossoms in Haiku of 'The Great Four'
}

\section{Muhammad Nadzif Bin Ramlan ${ }^{1}$}

Universiti Kebangsaan Malaysia (UKM), Malaysia

\begin{tabular}{|c|c|}
\hline Article History & Abstract \\
\hline $\begin{array}{l}\text { Keywords: } \\
\text { haiku; linguistics; } \\
\text { literature; discourse } \\
\text { analysis; cherry blossoms; } \\
\text { Great Four }\end{array}$ & $\begin{array}{l}\text { The proverb hana wa sakuragi, hito wa bushi highlights the significance of cherry } \\
\text { blossoms (sakura) as the pinnacle of Japanese aesthetics and floral symbolism. This } \\
\text { paper constructed a discourse analysis of cherry blossoms portrayed in the haiku by } \\
\text { the Great Four - namely Matsuo Basho, Yosa Buson, Kobayashi Issa and Masaoka } \\
\text { Shiki. Three poems from each poet were analyzed as samples, accumulating to } 12 \\
\text { haiku overall. To avoid equivocality, all } 12 \text { haikus observed would explicitly mention } \\
\text { sakura with its kanji character or hiragana. The analysis would cover linguistic } \\
\text { aspects and metaphorical interpretations associated to convey the portrayal of } \\
\text { cherry blossoms in the context of that haiku. Further discussion of the analysis would } \\
\text { have the creative representations of cherry blossoms among the four esteemed } \\
\text { poets to be compared in six aspects - time, imagery, state, rhetoric, idiomatic } \\
\text { expression and contrasting quality. With both linguistic aspect and relativistic } \\
\text { viewpoint to form the discourse analysis, this shows that cherry blossoms can act as } \\
\text { a form of display for personal philosophical values and personalities of the four } \\
\text { Japanese poets specifically as well as the Japanese society in general. }\end{array}$ \\
\hline
\end{tabular}

\section{Abstrak}

\section{Kata Kunci:}

haiku; linguistik; sastra; analisis wacana; sakura; Empat Besar

\begin{abstract}
Hana Wa Sakuragi: Analisis Wacana Bunga Sakura di Haiku 'Empat Besar'
Pepatah hana wa sakuragi, hito wa bushi menyoroti pentingnya bunga sakura (sakura) sebagai puncak estetika dan simbolisme bunga Jepang. Tulisan ini mengkonstruksi analisis wacana bunga sakura yang digambarkan dalam haiku oleh Empat Besar - yaitu Matsuo Basho, Yosa Buson, Kobayashi Issa dan Masaoka Shiki. Tiga puisi dari setiap penyair dianalisis sebagai sampel, terkumpul menjadi 12 haiku secara keseluruhan. Untuk menghindari keragu-raguan, ke-12 haiku yang diamati secara eksplisit menyebutkan sakura dengan karakter kanji atau hiragananya. Analisis mencakup aspek linguistik dan interpretasi metaforis yang terkait untuk menyampaikan penggambaran bunga sakura dalam konteks haiku itu. Diskusi lebih lanjut dari analisis membentuk representasi kreatif bunga sakura di antara empat penyair terhormat untuk dibandingkan dalam enam aspek - waktu, citra, keadaan, retorika, ekspresi idiomatik dan kualitas kontras. Dengan kedua aspek linguistik dan sudut pandang relativistik untuk membentuk analisis wacana, hal ini menunjukkan bahwa bunga sakura dapat berperan sebagai bentuk tampilan nilai-nilai filosofis pribadi dan kepribadian dari empat penyair Jepang pada khususnya serta masyarakat Jepang pada umumnya.
\end{abstract}

Corresponding author:

${ }^{1}$ a177919@siswa.ukm.edu.my 


\section{Introduction}

The Edo period proverb, 花は桜木人は武士 (hana wa sakuragi, hito wa bushi) lexically means "among flowers, cherry blossoms; among people, samurai/warriors". The adage implies that, much as the cherry blossom (sakura) is the most beautiful flower, the warrior (samurai, also known as bushi in Japanese) was the most powerful man. The samurai was also compared to a cherry blossom because, although his life was beautiful, it was prone to a quick end during military duty, much like the petals shed by cherry blossoms due to its ephemeral nature (Blomberg, 2013). This implies a profound connection between Japanese culture and the tree. From the proverb, there are two major concepts about the symbolism of cherry blossoms in Japanese literature: 1) Cherry blossom tree is dignified and prestigious in that it has the highest standards to be compared with samurai, and 2) poetry and idiomatic expressions will usually refer to cherry blossoms despite using the kanji character for flower, 花 (hana). Sakura uses the contemporary Kanji character 桜 although the classical form 櫻 still lurks in literary works and listed in the Jinmeiyō kanji list (Kanji characters specifically for people's names). Yuwana (2010) explained morphologically that Sakura is derived from the character 咲 (saku) meaning "to bloom" followed by the suffix $ら$ to indicate "many". The word sakura thus literally means "the blooming ones" and perfectly describes its nature.

Cherry blossoms are symbolic of a time of rebirth, the transitory aspect of life, the feebleness of beauty, the importance of the present, and so much more in Japanese culture. All of these ideas have been treasured in Japan since ancient times. Cherry blossoms' beauty is reflected in a broad range of consumer products, including kimonos, stationery, cooking equipment, and paintings. Few people realize that, in addition to the beauty of cherry blossoms, wood and bark, as well as wood fibre, may be used to make koto (a kind of traditional Japanese musical instrument) because the cherry blossom tree's wood is dense, robust, and may endure for tens to hundreds of years (Rhafiny et al., 2020). Cherry blossoms are also deeply related to Japanese society from a religious perspective. In Shintoism, there is a concept known as 誠 (makoto), meaning sincerity. The characteristics of Japanese people who value honesty can be strongly related to nature, particularly in light of nature's impermanence (Yanuarita, 2013) and this concept is parallel with the cyclical blooming of the cherry blossoms.

Cherry blossoms have been deeply entrenched in the hearts of Japanese people, as shown by the many places where cherry blossoms are admired and adored for their beauty and loveliness. Moreover, it turns out that cherry blossoms, which bloom in the spring, playing a significant role in Japanese people's lives, such as building family bonds, forming friendships, and creating excellent communication with coworkers or business partners, among other things (Hastuti, 2015). It is not surprising that many poets write songs about cherry blossoms when remembering family, lovers, and loved ones while watching and appreciating the blossoming flowers. Therefore, it is imperative to look into the poems crafted by the four most prominent Japanese poets, also abbreviated as 'The Great Four'. Three of them are from the Edo era - Matsuo Basho, Yosa Buson, and Kobayashi Issa - whereas Masaoka Shiki emerged during the later Meiji period. Persinger (2013) elucidated each of the poet's contributions to Japanese poetry as follows:

"These four writers are generally under stood to have directly shaped haiku into the art form that it is today: Basho elevated the haiku out of its comic base into a higher art form; Buson turned it into a very literary form; Issa gave haiku its personal touch; and Shiki is the one who 
Ramlan, MNB., (2021). Hana Wa Sakuragi: Discourse Analysis of Cherry Blossoms in Haiku of 'The Great Four'. Japanese Research on Linguistics, Literature, and Culture 4 (1), 1-15. https://doi.org/10.33633/jr.v4i1.5285

insisted that haiku was a viable art form during the time when haiku and other Japanese works were considered quaint and outdated." (Persinger, 2013:2)

Japanese poetry is not limited to haiku/hokku; it is only a few first lines of the exorbitantly long aristocratic renga. However, the entry in Cambridge Dictionary for haiku is a symbol of international recognition upon the Japanese poetry, albeit its incorrect morphological description of haiku as the 17 'syllables' instead of morae.

Looking back at previous research, they were focused on the symbolism/aesthetics of cherry blossoms. The studies highlighted the role of cherry blossoms from a historical perspective (folklore and nationalism) or a contemporary one, such as in advertising and cultural exchanges. There has been a great deal of shift in connotations associated with the flower over the course of Japanese history, from its early image of production and reproduction to its later associations with mortality and nonproductive sexuality such as transgender geisha and same-sex relationships (Ye, 2015). Furthermore, the metaphorical meaning of cherry blossoms as the beauty of life, commonly connected with the beauty of females, shifted to the advocacy of the beauty of death, namely the suicide efforts of warriors or kamikaze pilots as a demonstration of devotion (Ohnuki-Tierney, 2010). This multifaceted view of the symbolism highlights Zen's own contradictions concerning the reality of the situation for that conflicting assertions to coexist harmoniously.

Therefore, anthropologists and philosophers attempted to connect haiku with the aforementioned symbolism. Lanoue (2008) described a couple of Kobayashi Issa's haiku on cherry blossoms to be interpreted symbolically as the embodiment of the poet's own ideals regarding the style of cherry blossoms drifting to oblivion while faithfully trusting in the Buddha. Looking at the portrayal of cherry blossoms in Issa's haiku from a religio-cultural perspective, Lanoue (2008) posited that "in the poet's view, all living things, including plants, find themselves on the same cosmic pilgrimage towards enlightenment" (p.162). Philosophers such as Takamatsu (2019) extracted philosophical views from the haiku written by Matsuo Basho, particularly in the area of epistemology, albeit the researcher preferred more popular haiku over the ones containing cherry blossoms in the analysis.

However, literary scholars often prioritized Basho's haiku, rendering the other three in the list to be severely underwhelmed, let alone discussing specific themes such as cherry blossoms. Even more so, scholars would highlight the artistic perspective of these poets compared to their poetic work. For instance, one of the Great Four, Yosa Buson, was also known as a painter, and thus scholars such as Inose (2017) focused on Buson's artistic work of Bunjinga (文人画, “literati painting") rather than his haiku. Although Kisanuki (2002) made an analysis of Masaoka Shiki's haiku, another member of the Great Four, but the emphasis was put on the relatability of Shiki's view on Noh dance (能) in the haiku and his theory of the traditional performance. Besides that, haiku analysis was done via literary criticism, thus showing little endeavors to relate the syntactic structures and linguistic aspects along with the imageries in order to ascertain the emotion of the respective haiku. Isla (2017) depicted an imagery in a haiku to be describable in one, two, or three words; an effective haiku is one that strikes the proper balance between speaking too much and not enough. This explanation was vague and this underplayed the actual role of linguistic stylistics in haiku. Psycholinguists such as Minagawa (2017) presented results regarding the construction and interpretation of haiku amidst the contemporary societies. Nonetheless, this would mean that the relativistic viewpoint of certain items such as cherry blossoms and Japanese diachronic syntax of contemporary haiku would differ from the haiku during the Great Four's era. Hence, this study 
would fill in the literature gap regarding linguistic stylistics as well as the comparative study of haiku among the four poets regarding cherry blossoms, the main symbolism in this study. This study also serves as an expository attempt to centralize these four poets for stylisticians and literary scholars to consider in their future research.

The haiku by the Great Four which had been chosen would be analyzed via the methods described in the next section.

\section{Methods}

The observation would be explained via qualitative description upon the representation of cherry blossoms in each of the haiku. Three poems from each of the four authors would be chosen as the sample, resulting in 12 haiku overall. The haiku was primarily acquired and rechecked via books and university database such as Basho: The Complete Haiku by (Reichhold, 2013) and University of Virginia for Masaoka Shiki's haiku. The haiku for other two poets, Yosa Buson and Kobayashi Issa, had been obtained from various Japanese websites (e.g., https://idea1616.com/buson/). To avoid any sort of ambiguity, the chosen haiku explicitly mentioned Sakura by its kanji character, whether the contemporary 桜 or the classical 櫻, or even its hiragana form $さ<ら$. The overall process to explicate the significance of the haiku would be known as discourse analysis. Discourse analysis is a set of techniques for analyzing the content, sociopolitical relevance, and interactional consequences of semiotic activities in order to illustrate how they affect social processes in a systematic way (Dick \& Nightlinger, 2020).

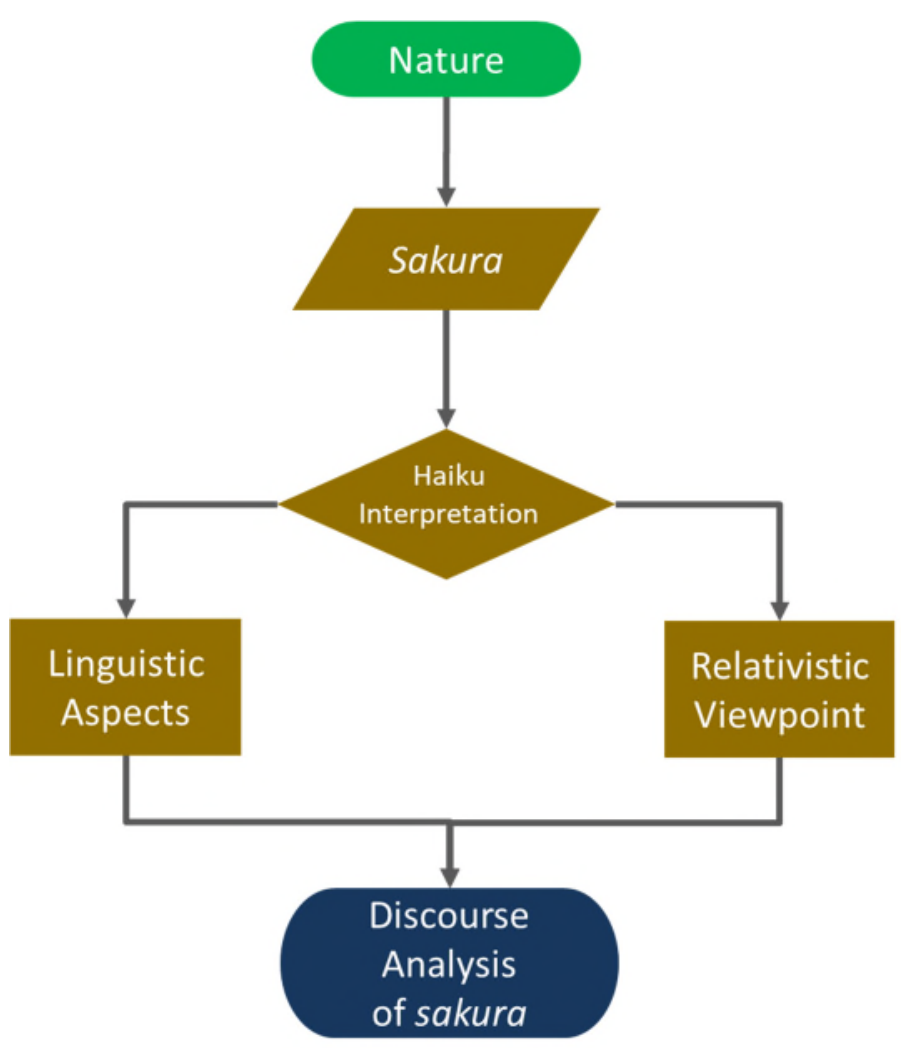

Fig.1 Conceptual Framework for Discourse Analysis of sakura 


\section{Results and Discussion}

\subsection{Matsuo Basho's Haiku}

$\begin{array}{lll}\text { 顔に似ぬ } & \text { 発句も出でよ } & \text { 初桜 } \\ \text { kao ni ninu } & \text { hokku mo ideyo } & \text { hatsuzakura }\end{array}$

The lexical meaning of this haiku is "it does not represent my face; even the haiku that appear; first cherry blossoms”. The verb 似ぬ is in negative form, which means it did not resemble, or to some extent, unworthy. The inclusive particle $\&$ here linked the previous statement with the haiku that he wrote. Hatsuzakura 初桜 means the first budding cherry blossoms of the year.

To link these 3 premises, Brown (2020) opined that Basho's message here was "poetry should have the freshness and promise of a cherry blossom and not old and weary like the poets." However, this depiction of 'face' relates to physiognomy - studying a person's character or personality based on their external appearance, especially their face. By combining rhetorical analysis, cognitive literary theory, and digital techniques, Trigg et al. (2020) sought to build a complete knowledge framework about evolving literary and textual discourses in physiognomy. Therefore, rather than emphasizing the vitality of the haiku, the nuance of this haiku can also be directed towards kao in which it represented the most recognized appearance of a person at first sight, yet it could not comprehensively portray any individual due to the complex nature of a human being.

$\begin{array}{lll}\text { 姥桜 } & \text { 咲くや老後の } & \text { 思い出 } \\ \text { ubazakura } & \text { saku ya rōgo no } & \text { omoiide }\end{array}$

This haiku's semantic meaning is "granny-cherry; the blooming of the past; reminiscence". The Kanji 姥 is generally referred to as an old woman, but the Chinese character specified it as 'maternal grandmother', thus translated as granny-cherry. The possessive particle $\odot$ connects the remembrance of her 'blooming' bygone days when youth and beauty still had a hold on her, now fading away.

Gill (2006) expressed that some poets regarded this as one of Basho's worst poems due to his then-strong association with Matsunaga Teitoku's school of poetry during the early Edo period known as Teimon. It is possible to define the attitude toward composition that followed from the school's acceptance of haikai's status as a fundamentally inferior variant of renga as being best described as grudgingly restrictive. This led to conjectures by certain Japanese linguists to the conclusion as mentioned by Gill (2006). Despite that, it is plausible to differ about this issue because this particular haiku conveys a strong emotional yet succinct message for the readers. The oxymoronic amalgamation of cherry blossoms that invigorate every year with a deteriorating woman with every passing moment is solidified with the synergy of nostalgia and melancholy.

$\begin{array}{lll}\text { さまざまの } & \text { 事思い出す } & \text { 櫻かな } \\ \text { samazama no } & \text { koto omoidasu } & \text { sakura kana }\end{array}$


This haiku can be translated as "variety of things I remember, cherry blossoms I wonder...".

さまざま has its Kanji character 様, that is more recognizable for its suffix -sama as an honorary manner of speech in keigo. This reduplication due to the repetition of word stem had been observed by Fujimura (2001) when comparing standard Malay and Japanese, equating the morphological structure of samazama with macam-macam (various-various). いろいろ also carries an equivalent meaning. Meanwhile, かな has its archaic Kanji character 哉 that is usually translated as "how", "why" and "alas" because some translators perceived its nuance as a form of sadness and regret. However, it is best to be neutral and to fit in its contemporary usage, thus depicting it as a pure curiosity and/or rhetorical device.

Sakura is widely regarded as a rebirth symbolism. Historically, cherry blossom trees were thought to symbolize mountain deities who changed into gods of rice fields in Japanese traditional religions. They also represented agricultural reproduction. The Japanese traveled to the highlands every spring to worship the trees, then transplanted them to populated regions. As a result, cherry blossoms have traditionally signaled the start of spring, a season of rebirth and hope. Because the blooming season coincides with the start of the Japanese calendar year, they offer optimism and new dreams at a time when children begin their first day of school and workers begin their first day of a new job. These refreshing experiences would be some of the most iconic moments in a person's life. Therefore, the collocate of rhetoric 哉 with cherry blossoms would imply the blossoming of the flowers as the trigger for flashbacks and 'variety of things' in mind.

\subsection{Yosa Buson's Haiku}

$\begin{array}{lll}\text { さくらより } & \text { 桃にしたしき } & \text { 小家哉 } \\ \text { Sakura yori } & \text { momo ni shita shiki } & \text { ko ie kana }\end{array}$

The literal translation of this haiku is "comparing the cherry blossoms, peach blossoms underneath (would fit), this small house I wonder". The comparative form $よ り$ is used between cherry blossoms and peach. It is generally understood that cherry blossom trees are bigger and more majestic rather than the smaller momo (peach) tree.

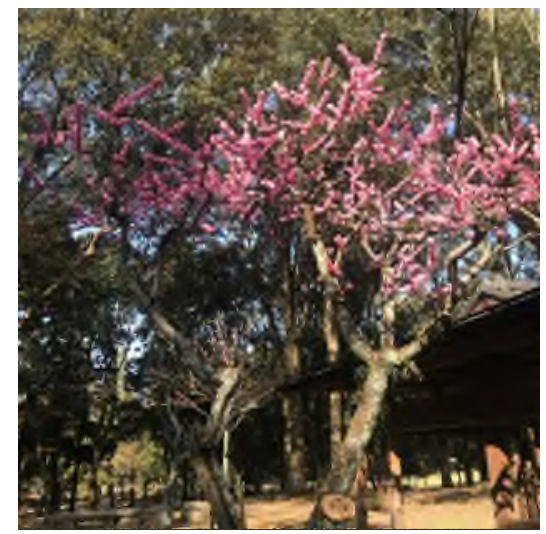

Picture 1. Peach trees at Nara Park [Source: The author, dated $27^{\text {th }}$ March 2018] 
Buson was known to be an enthusiast of Chinese poetry, spending a lot of time reading Chinese and Japanese classics and idolizing Matsuo Basho. All of this, along with Buson's tremendous inventiveness, allowed an inner flame to burn brilliantly inside his creative spirit (Walker, 2017). However, it is intriguing to observe the differences in their chosen lexis to be incorporated into their haiku, as Basho tended to use sakura in his Haiku, Buson often used other flowers to convey his imagery in poetry such as momo 桃 or 白梅 (shiraume, white plum flowers). This means individuality holds in artistic work despite following the footsteps of his mentor. Furthermore, the noun phrase that Buson used in this haiku, 小家 (a small house) denoted a humble and inferior description as he gazed into his thought.

$\begin{array}{lll}\text { 木の下が } & \text { 蹄のかぜや } & \text { 散さくら } \\ \text { Ki no shita ga } & \text { Kitzume no kaze ya } & \text { chirusakura }\end{array}$

The lexical meaning of this haiku is "under the tree; the wind of the horse hooves; scattering cherry blossoms". At first glance, using nouns to depict orientational nouns such as kitzume, kaze and chiru could illustrate the heating moments in a battlefield or a chaotic scene in general. Meanwhile, the adverb of place such as shita indicates a fixed or stationary point of view under the tree.

Buson was referring to the description of the poem by Du Fu, a poet of the Tang dynasty in the $8^{\text {th }}$ century, in which the poem was later adapted into Japanese literature via the story of the popular horse named Kinoshita. The heating battle that ensued due to a certain incident regarding the horse led the people who lost the war to reminisce the moment under a tree with the vivid description in this haiku. In this aspect, the collocate 散さくら describes the cherry blossoms as the scattering petals, adding it into the lexical repertoire of sakura in Japanese language.
ゆき暮て
雨もる宿や
糸ざくら
Yuki kurete
ame moru yado ya
itozakura

The lexical meaning of this haiku is "the vanishing snow; the rain leaks (into) the inn; the weeping cherry blossoms". (Persinger, 2013) translated it as "melting snow; drips through a crack in the roof; cherry petals" although this would be perceived as inaccurate due to the generalization of the 'roof'. 暮て indicates continuing action followed by the verb もる (漏る as its kanji character). The cherry blossoms are described with the kanji character 糸, which means "thread", a long, thin strand of cotton used for sewing. Due to its downward posture and weak material stability, itozakura inherits that particular form and is even called the "weeping cherry blossom tree", as shown in Picture 2 below.

Carter (2020) explained that transplanting itozakura has a significant failure rate because the stress on the roots and leaves may lead them to wilt and die, particularly if the plant is young. As the features used in this haiku, such as 'snow', 'vanish', 'leaks' and 'weeping' along with the two consecutive verbs in the haiku are concerned, it is clear that this haiku has a sombre mood despite soon encountering spring after the harsh winter. 


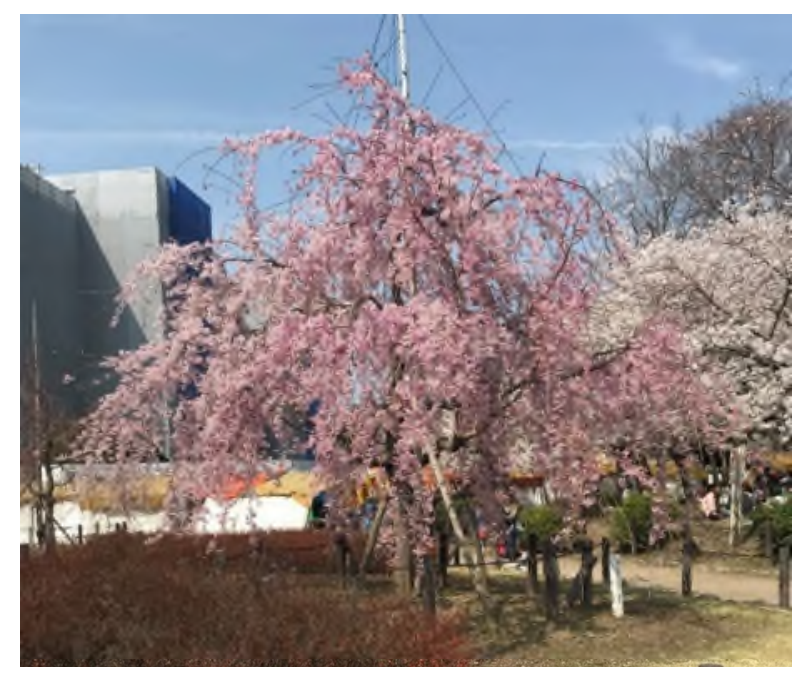

Picture 2. Itozakura at Tsurumai Park, Nagoya

[Source: The author, dated $26^{\text {th }}$ March 2018]

\subsection{Kobayashi Issa's Haiku}

$\begin{array}{lll}\text { 苦の娑婆や } & \text { 桜が咲けば } & \text { 咲いたとて } \\ \text { Ku no shaba ya } & \text { sakura ga sakeba } & \text { saita tote }\end{array}$

"The agony of this world; if the cherry blossoms bloom; even though they bloom" is the lexical meaning of the haiku. A standardized translation is "a world of grief and pain; flowers bloom, even then". This haiku is rooted in Buddhism as the kanji 苦 is used to describe the eight pains/suffering that humans inevitably go through such as birth, aging, sickness, and death. The other four are explained in Nishiren Shu:

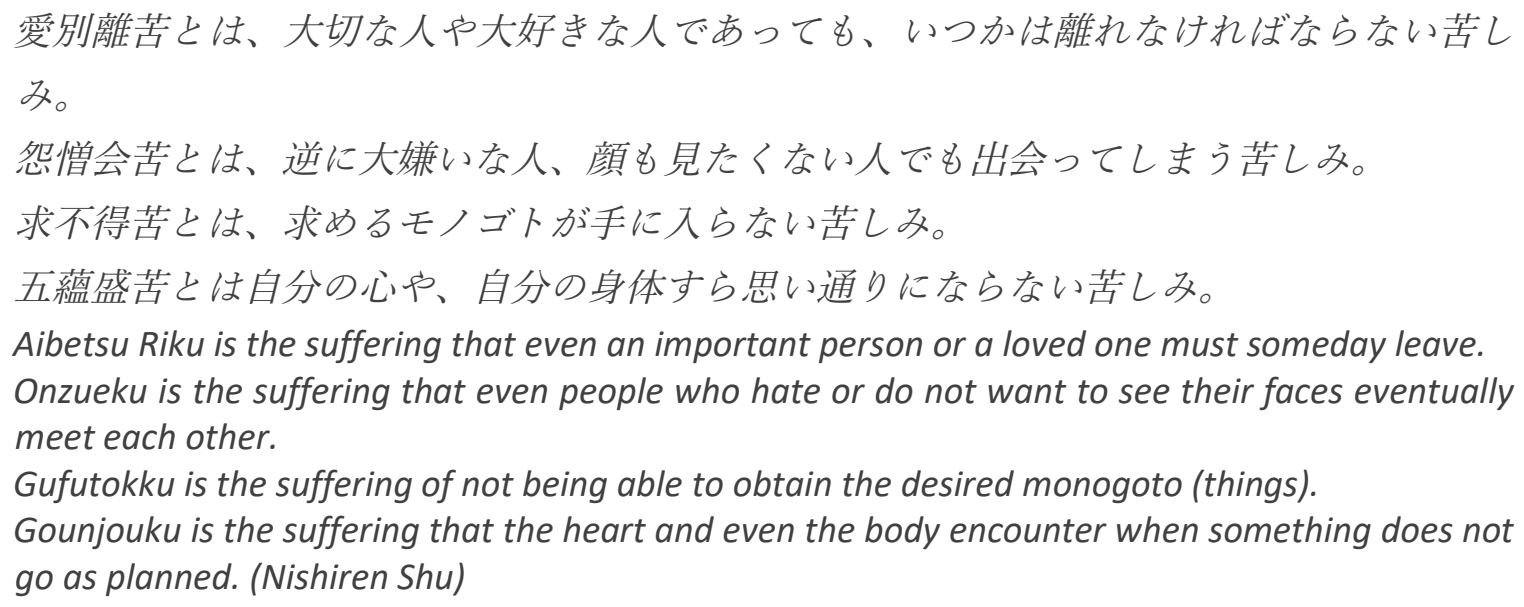

娑婆 (shaba) is also meant as 'corrupt world' in Buddhism. The two verbs, 咲けば and 咲いた $と て$, respectively in the provisional present indicative form and plain past indicative form 
followed by the conditional particle $と て$, indicated utter confusion in anchoring the temporal deixis (due to the clash in time frames between present and past). This elucidated pandemonium in this world despite "cherry blossoms blooming" to designate the start of a new era. This strong emotion was brought forth with a philosophical perspective of Buddhism, strengthening the concept of mono no aware.

$\begin{array}{lll}\text { 桜咲く } & \text { 大日本ぞ } & \text { 日本ぞ } \\ \text { Sakurasaku } & \text { dai nippon zo } & \text { nippon zo }\end{array}$

The literal meaning of this haiku would be "the blooming cherry blossoms; big Nippon; Nippon". The intransitive verb 桜咲 $<$ is an idiomatic expression - to wish someone success in an assessment or an examination, with the imagery of blooming sakura as a symbol of positivity and fortune. The interesting aspect of this haiku is the epizeuxis for 日本. Epizeuxis, originating from

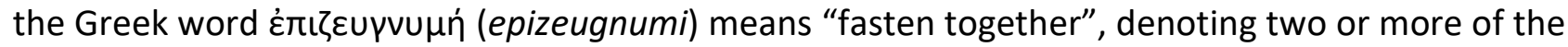
same word in immediate succession. This rhetorical device gives a message of emphasis and vehemence. This style aligns with the colloquial masculine particle $゙$, often employed to finish their statements with appropriate intensity and uncompromising conviction.

In this haiku, Issa's focus is clear: sakura and nippon. This is as if to correlate cherry blossoms with the land of the rising sun. Despite the imperial family having their royal crest with the features of a chrysanthemum, cherry blossoms are commonly referred to by the Japanese and foreigners alike as Japan's informal national flower. The breathtaking cherry blossoms, selected as a national emblem during the Nara era from $710 A D$ - $794 A D$ to distinguish it from China's plum blossoms, have been deeply entrenched in Japanese identity and history (Gillingham, 2019). This developed into a form of national pride and even a symbol of sacrifice for the emperor's sake during the turbulent World War II. Yaba (1992) even mentioned that this haiku pictured the unique style of Kobayashi Issa.

$\begin{array}{lll}\text { 茶屋むらの } & \text { 一夜にわきし } & \text { 桜かな } \\ \text { Chaya mura no } & \text { ichi ya ni wakishi } & \text { sakura kana }\end{array}$

The lexical meaning of this haiku is "the tea-stall village's; staying overnight; cherry blossoms I wonder". Both the temporal aspect and the spatial aspect exists with 一夜 and 茶屋む $\zeta$ respectively, giving an overview of the current location of the interlocutor at the time this haiku was written. The 'tea-stall village' existed due to businesses and small stalls opening at hanami sites to accommodate people spending their time, even sleeping at those places. Therefore, the rhetorical device he used, かな, was to inquire whether he could get either hanami or the tea-stall village. However, since both need to be present at the same place, he merely cherished the moment he could savour both during the event. Noticing that this haiku used the kanji character 茶, this haiku could also serve as a form of identity for Issa, since his pen-name 一 茶 literally means 'a cup of tea'. 


\subsection{Masaoka Shiki's Haiku}

$\begin{array}{lll}\text { 夜桜や } & \text { 人静まりて } & \text { 雨の音 } \\ \text { Yozakura ya } & \text { hito shizumarite } & \text { ame no oto }\end{array}$

"The night cherry blossoms; the people quieten down; the sound of the rain" is the lexical meaning of this haiku. The collocation 夜桜 delineated the time frame of this haiku being written. The intransitive/godan verb 静まりて is in a connective form with the particle $て$. The verb told us that people would halt their communal activities and disperse to their respective homes as nighttime came. The silence that later came on the scene then blanketed the whole area, only to hear the sound of the dropping rain.

Nighttime had a unique set of cultural values that extended well beyond the reversal of daylight. The night was a mythical character, a repository of specialized information, a socially important semantic area in various literary genres, and a setting for one-of-a-kind experiences (Ker \& Wessels, 2020). Therefore, tranquility is the theme of this haiku since only the 'voice' of nature was heard, and the night cherry blossoms set in the mood.

$\begin{array}{lll}\text { 一重づっ } & \text { 一重づく散れ } & \text { 八重桜 } \\ \text { Hitoezutsu } & \text { hitoezutsu chire } & \text { yaezakura }\end{array}$

This haiku's semantic meaning is "single layer; single layer scattered; the eight-layered cherry blossoms". This poem was translated based on the database in the University of Virginia as "scatter layer, by layer, eight-layered cherry blossoms". This haiku also included epizeuxis with the successive repetition of 一重づ instructed due to the verb 散れ in its imperative plain present indicative form.

The description of the cherry blossoms in this haiku is eight-petal (although not really the case in some observations), commonly known as yaezakura, a double-layer kind of sakura known for its elegance and resilience. The typical one-layer sakura is frail and easily blown away by high winds or rain, but not for this type of cherry blossoms. Yaezakura was known during the medieval times to be only available on the Yoshino mountain in Nara prefecture, in which Yosa Buson explicitly mentioned the mountain by name in his haiku, 雲を吞んで/花を吐くなる/吉野山 which means "drinking up the clouds; it spews out cherry blossoms; Yoshino Mountain" (Joy, 2017).

Furthermore, the association of the cherry blossoms with the number eight (8) has a different reason in Japanese culture than Chinese belief. Samukawa Shrine explained the concept of blessings that the number eight ( 8 ) holds in Japanese culture:

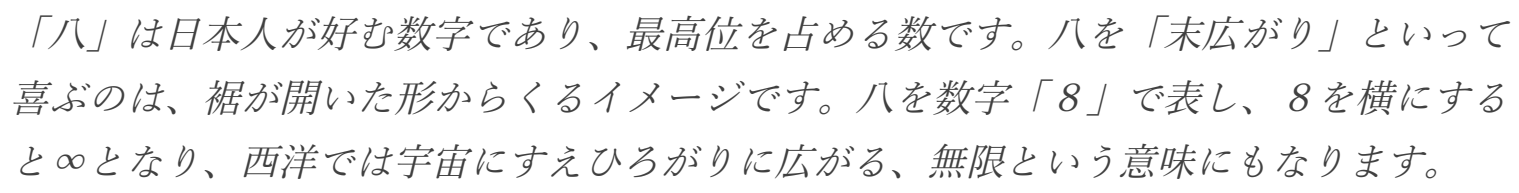


"8 is a number that Japanese people like and occupies the highest rank. What makes us happy when we call Hachi "spreading toward the end" is the image that comes from the open hem. Eight is represented by the number " 8 ", and when 8 is laid down, it becomes $\infty$, and in the West it also means infinity, which spreads throughout the universe." (Samukawa Shrine)

When comparing this concept of 'eight' and the 'scattering', this can be contradictory because the latter is more inclined towards hinting at a bad omen and the like. Thus, this haiku has a strong disconcerted feeling associated with the actions done upon the eight-layered cherry blossoms.

$\begin{array}{lll}\text { しんとして } & \text { 露をこぼすや } & \text { 朝桜 } \\ \text { Shin to shite } & \text { Ro o kobosu ya } & \text { asazakura }\end{array}$

This final haiku for the observation is translated literally as "the continuing silence; dew spills; the morning cherry blossoms". The verbしんとして might be homophonic to 神道 (Shinto, a native Japanese religion) for non-Japanese natives, thus making it confusing at first sight. $L ん$ is an adverbial onomatopoeia to express "quietness" or "silence". According to Tanahashi and Toshiro (2016), "various adverbial onomatopoeia combined with the conjunction particle $と$ and the verb する (do)." Hence, in this case, it follows the format しん+と+して (conjunctive form). The following verb, こぼす (零す with kanji character) described the spilling dew with the 'morning' cherry blossoms as the background. Friedman (2006) expressed the notion of asazakura as invigoration or rejuvenation. Time collocates have been popular as attributes to cherry blossoms, and this one provides rejuvenation, spiritual renewal, and a good start of a new day.

\subsection{5 Cross-Sectional Analysis}

Based on the 12 haiku that have been analyzed, there are several important aspects among the four poets in describing the cherry blossoms. The first one is the temporal aspect (time). Shiki portrayed cherry blossoms with the universal time (asa 朝 and yo 夜) whereas Basho described the particular moment with a relative time (hatsu 初). These two antithetical perspectives are based on the relative view of the interlocutor, whether the individual acts as an observer of routine occurrences such as sunrise and sunset, or a discoverer in which new experience has been received. In other words, it is the contrast between a priori and a posteriori knowledge. Kisanuki (2002) respectively described Basho and Shiki as "the one who seeks the truth of humanity" and "expresses ordinary daily life" (p.1). Another interesting aspect is that the different phases convey unique 'energies' that correspond with typical activities done by humans during those periods, and Friedman (2006) expounded the implicit meaning behind the collocates of cherry blossoms with time:

"Asazakura evokes a sense of freshness. It is the cherry blossom and the world without any pretense. Yuuzakura implies a feeling of quiet, before the darkness of the night has sets in. Yozakura is fully night. It evokes a more luscious mood than "morning blossoms" might, for example." (Friedman, 2006:155) 
Ramlan, MNB., (2021). Hana Wa Sakuragi: Discourse Analysis of Cherry Blossoms in Haiku of 'The Great Four'. Japanese Research on Linguistics, Literature, and Culture 4 (1), 1-15. https://doi.org/10.33633/jr.v4i1.5285

The second aspect is imagery. In this case, Shiki and Basho had their ingenious personifications and descriptions of the cherry blossoms for yaezakura 八重桜 and ubazakura 姥桜 respectively. They immaculately connected the iconic flowers in Japanese culture with the intricacies of Japanese belief about the number " 8 " and vivid imagery. Regarding yaezakura 八重桜 however, it is not strictly unique to Shiki since Basho also used such attribute earlier in one of his haiku: 奈良 七重七/堂伽藍/八重ざくら which means "the seven buildings of the temple compounds in Nara, eight-layered cherry blossoms". Moreover, the narrative of "granny-cherry" is unlike what other later poets would have done. Therefore, Basho is the supremo in this aspect, as Kawamoto (1999) glorified him, "Basho's haiku and the poetry of the imagists are the two most prominent examples of extremely short poetic forms in world literature" (p.1).

The third aspect is the state of the cherry blossoms. In the analysis, two of Buson's haiku used chiru 散 and ito 糸 to illustrate the situations in which the cherry blossoms were concerned. Both portrayals are compatible with the ambiance in the respective haiku. The scattering cherry blossoms symbolize chaos and uneasiness, whereas the kanji for thread (糸) corresponds with the lethargic condition, amplified with the actual referent in real life, as shown in Picture 2 . With the sensuous and picturesque chronicles in his haiku, it is unsurprising if Miura (1991) panegyrized Buson's poetry as "pictorial, lyrical, and often displays a delicate sensitivity" (p.12).

The fourth aspect is rhetoric. Basho and Issa use the rhetorical device kana かな. Influential speakers historically used the strategy of presenting questions they expect no answer as a powerful persuasion tool. In the case of classical literature, even rhetorical techniques were implemented in Chinese manuscripts (Indraccolo, 2021) and earlier Japanese poetry such as renga (Carter, 2011) to bring forth strong resolution and emotion while considering various other linguistic aspects in the making of the texts. Hence, both esteemed poets utilized this approach to emphasize the evocative symbolism related to cherry blossoms: reminiscence and one's lifetime personal recollection of anecdotes.

The fifth aspect is an idiomatic expression. This part is unique to Issa as he used sakurasaku 桜 咲く which has been explained in the previous discussion to connotate success in the figurative speech of modern Japanese. The effect of idiomatic expression in haiku can be viewed from a robust manner via functional discourse grammar (FDG), in which it considers cognitive linguistics as part of the analysis, similar to that of a metaphor. Coherence is also considered to cope with semi-fixed constructions despite the distinctive difference between lexicon and grammar (Keizer, 2016). This style is indeed creative and befitting Issa as a member of The Great Four.

The final one is regarding contrast. Issa and Buson used this approach to channel their individuality in their haiku. Issa used the different tenses for the same verb 咲 $<$ and this abstract comprehension in grammar certainly plays a part in Issa's creativity of this haiku. Meanwhile, Buson employed different 'props' in the haiku - momo (peach) against sakura (cherry blossoms). Despite the fact that both flowers have the same pink hue, the shades are different, with the former being darker than the latter, as shown in Picture 1. Considering other dissimilarities discussed in the previous section, Issa and Buson expressed individuality in their haiku via their broader outlooks, particularly on cherry blossoms. 


\section{Conclusion}

The overall representation of cherry blossoms in the entirety of Japanese poetry especially haiku would only bring injustice to consider only 12 of the haiku by The Great Four. However, we can infer from our discussion above that cherry blossoms can be specified and portrayed according to many factors, such as time (朝桜, 夜桜, and 初桜), imagery (八重桜 and 姥桜), descriptive quality (糸ざくら and 散さくら), rhetoric (櫻かな), idiomatic expression (桜咲く) and comparison (さくらより and 桜が咲けば). Time can be universal or relative to interlocutors in the haiku depending on the collocations, denoting a priori and a posteriori knowledge in the work of Basho and Shiki. The imagery remains an essential element to represent cherry blossoms, and this showcases Basho's poetry prowess, followed by Shiki's adaptability. The different states provided by Buson could provide the ambiance of the haiku associated with the cherry blossoms. Rhetoric was apparent in the haiku written by Basho and Issa in ascertaining the presence of cherry blossoms throughout life of a Japanese.

Meanwhile, Issa shone in exclusive splendor when availing himself of his haiku with the idiomatic expression that still holds pertinence in the contemporary Japanese society. Finally, the compelling comparisons by Issa and Buson broaden one's view about notions related to cherry blossoms, such as differences in tenses and comparison with peach trees, respectively. These perspectives, along with linguistic stylistics conducted upon the haiku to collaboratively form the discourse analysis of cherry blossoms, can only propel the view that this flower has had its consolidated position in Japanese civilization since time immemorial.

The omnipresent cherry blossoms, with their white and pink petals that scatter in the wind, have always been linked with Japan (Nippon) and Japanese society and will continue to be the case. For centuries, they have stood for everything from the land and its people to youthful exuberance, passion to creation, fertility to beauty, purity to the fleeting nature of life, and the brave demise of soldiers. Nothing else has been the subject of as much study or as many artistic depictions, poetic descriptions, or idealizations as the sakura. The Japanese soldiers embraced this flower wholeheartedly throughout the 18th and 19th centuries to symbolize ultimate patriotism and loyalty. Henceforth, it is not an exaggeration to prove that the proverb hana wa sakuragi, hito wa bushi still holds its synergy and relevance today.

\section{References}

Blomberg, C. (2013). The Heart of the Warrior: Origins and Religious Background of the Samurai System in Feudal Japan. Routledge.

Brown, B. A. (2020). Itadakimasu! The Food Culture of Japan: いただきます! Routledge.

Carter, H. (2020). Complete Guide to Weeping Cherry Tree: How to Grow \& Care for Them. Garden Beast. https://gardenbeast.com/weeping-cherry-tree-guide/

Carter, S. D. (2011). Haiku Before Haiku: From the Renga Masters to Basho. Columbia University Press. 
Friedman, A. (2006). The Haiku Apprentice: Memoirs of Writing Poetry in Japan. Stone Bridge Press.

Fujimura, Y. (2001). Reduplication in Standard Malay and Japanese. Jurnal Bahasa Moden. 65-92.

Gill, R. D. (2006). Cherry Blossom Epiphany -- The Poetry and Philosophy of a Flowering Tree. Paraverse Press.

Gillingham, T. (2019). How to Enjoy Cherry Blossom Viewing in Japan. Wayfairer. https://www.wayfairertravel.com/inspiration/cherry-blossom-viewing-in-japan/

Hastuti, N. (2015). Daya Tarik Bunga Sakura Bagi Masyarakat Jepang. Jurnal Izumi, Volume 5, No 1, 57-63.

Indraccolo L. (2021). Argumentation and Persuasion in Classical Chinese Literature. In: Bjelde J.A., Merry D., Roser C. (eds) Essays on Argumentation in Antiquity. Argumentation Library, vol 39. Springer, Cham. https://doi.org/10.1007/978-3-030-70817-7_2

Inose, A. (2017). Yosa Buson fude "oku no hosomichi-zu" to sono seisaku haikei ni tsuite. Higashiajia bunka kenkyū-ka insei-ron. https://core.ac.uk/download/pdf/228738552.pdf

Isla, N. R. (2017). Reviving Haiga: Interpreting and Painting the Haiku of Matsuo Bashō. The Asian Conference on Arts \& Humanities 2017. Official Conference Proceedings. http://papers.iafor.org/wp-content/uploads/papers/acah2017/ACAH2017 32966.pdf

Joy, A. (2017). Haiku Poetry About Japan's Cherry Blossoms. Culture Trip. https://theculturetrip.com/asia/japan/articles/haiku-poetry-about-japans-cherry-blossoms/

Kawamoto, K. (1999). The Use and Disuse of Tradition in Bashō's Haiku and Imagist Poetry. Poetics Today, 20(4), 709-721. http://www.jstor.org/stable/1773197

Keizer, E. (2016). Idiomatic expressions in Functional Discourse Grammar. Linguistics. Vol.54 No.5. https://doi.org/10.1515/ling-2016-0022

Ker, J. \& Wessels, A. (Ed.). (2020). The Values of Nighttime in Classical Antiquity: Between Dusk and Dawn. Brill. Vol.434.

Kisanuki, H. (2002). Shiki no haiku to nō. Nihon daigaku daigakuin sōgō shakai jōhō kenkyū-ka. No.3, 239-251.https://gssc.dld.nihon-u.ac.jp/wp-content/uploads/journal/pdf03/23-2392002-Kisanuki.pdf

Lanoue, D. G. (2008). The Haiku Mind: Issa and Pure Land Buddhism. The Eastern Buddhist, 39(2), 159-176. http://www.jstor.org/stable/44362411

Minagawa, N. (2017). Daigakusei ni yoru sōsaku haiku no shinri gengo-gaku-teki tokuchō no bunseki - kigo to kire no kinō o chūshin to shite. Nihon shinrigakkai dai-81 kai taikai. https://doi.org/10.4992/pacjpa.81.0 2B-059 
Miura, Y. (1991). Classic Haiku: A Master's Selection. Tuttle Publishing.

Nishiren Shu. Shikuhakku. https://www.nichiren.or.jp/glossary/id154/

Ohnuki-Tierney, E. (2010). Kamikaze, Cherry Blossoms, and Nationalisms: The Militarization of Aesthetics in Japanese History. Chicago: University of Chicago Press. https://doi.org/10.7208/9780226620688

Persinger, A. (2013). Foxfire: The Selected Poems of Yosa Buson, A Translation. PhD Thesis, University of Wisconsin-Milwaukee.

Reichhold, J. (2013). Basho: The Complete Haiku by Matsuo Basho. Kodansha International.

Rhafiny, Y., Irma, I. \& Dewi, K. I. (2020) Makna Bunga Sakura Bagi Masyarakat Jepang dan Kaitannya dengan Filosofi Wabi Sabi. Diploma thesis, Universitas Bung Hatta.

Samukawa Shrine. http://samukawajinjya.jp/en/happoyoke/

Takamatsu, M. (2019). Sekai haiku no kentō sekai haiku no kentō ni yoru dentō-tekina gengo bunka no sōtai-ka - - kokusai bakarorea TOK no shiten o toriirete ni yoru dentō-tekina gengo bunka no sōtai-ka. Kokugo-ka kyōiku, Vol.83. 42-50. https://doi.org/10.20555/kokugoka.83.0 42

Tanahashi, A. \& Tashiro, H. (2016). Say it like it sounds in Japanese with onomatopoeic verbs. The Japan Times. https://www.japantimes.co.jp/life/2016/09/05/language/say-like-soundsjapanese-onomatopoeic-verbs/

Tregg, S., Hughes, J., Bolens, G. \& Summer, T. D. (2020). Literature and the face: A critical history. University of Melbourne. https://arts.unimelb.edu.au/school-of-culture-andcommunication/our-research/research-projects/literature-and-the-face-a-critical-history

Walker, L. J. (2017). Yosa Buson and Japanese Poetry: In the footsteps of Matsuo Bashō. Modern Tokyo Times. http://moderntokyotimes.com/yosa-buson-and-japanese-poetry-in-thefootsteps-of-matsuo-basho/

Yaba, K. (1992). Chichi no shūen nikki oragaharu: Ta ichi-hen/Issa [shiru] yabakatsuyuki-kō chū. Tōkyō: Iwanami Shoten.

Yanuarita, Z. (2013). Mono no Aware Pada Peribahasa Jepang yang Menggunakan Kata Sakura. Japanology, Vol.1, No.2. 184-193.

Ye, H. (2015). A symbol becomes the culture: Reinventing Japanese cherry blossoms. Master thesis, Lund University. http://lup.lub.lu.se/student-papers/record/7861548

Yuwana, C. (2010). Makna Sakura Bagi Masyarakat Jepang. PARAFRASE: Journal of Linguistics, Literature and Cultural Studies, Vol. 10, No.1. 16-22. 